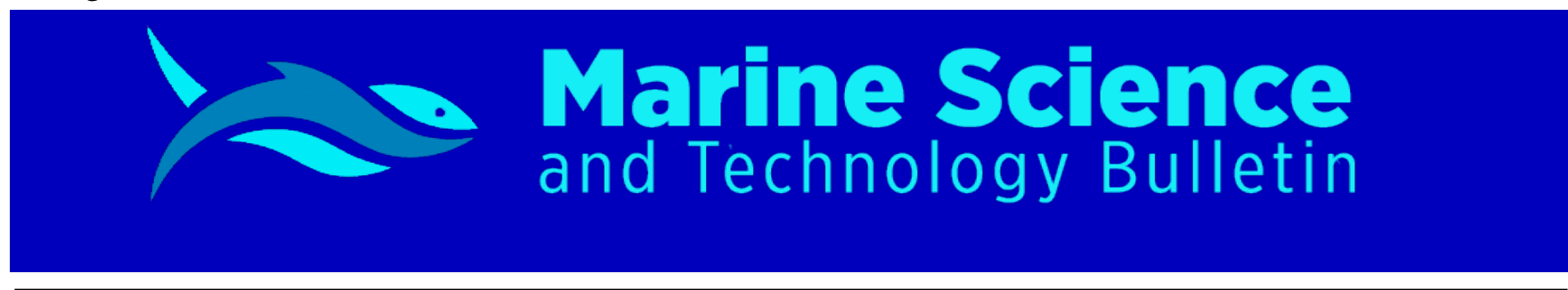

RESEARCH ARTICLE

\title{
Determining the relative efficiency of container terminals in Turkey using fuzzy data envelopment analysis
}

\author{
Ercan Yüksekyıldız ${ }^{1^{*}}$ (D) Ahmet Lutfi Tunçel ${ }^{2}$ (D) \\ ${ }^{1}$ Samsun University, Faculty of Economic, Administrative and Social Sciences, Department of Maritime Business Administration, \\ 55080, Samsun, Turkey \\ ${ }^{2}$ Iskenderun Technical University, Naval Architecture and Maritime Faculty, Maritime Transportation and Management Engineering \\ Department, 31200, İskenderun, Turkey
}

\begin{tabular}{|c|c|}
\hline A R T I CLE IN FO & A B S T R A C T \\
\hline Article History: & In this study, fuzzy data envelopment analysis (FDEA) was conducted to determine the \\
\hline Received: 30.03 .2020 & relative efficiency of the container terminals operating in Turkey. For this purpose, the data \\
\hline Received in revised form: 06.05 .2020 & from the container terminals were converted into fuzzy values using the "set of a cuts \\
\hline Accepted: 08.05.2020 & approach" and the upper and lower limit values for each terminal were determined. The \\
\hline Available online: 13.05 .2020 & lower and upper limit efficiency values were calculated using the input-oriented CCR- \\
\hline Keywords: & FDEA method. The minimax regret approach was used to sort and compare the relative \\
\hline Container terminals & efficiency of terminals. According to the resulting efficiency scores, one container terminal \\
\hline Efficiency analysis & was effective at all a cutting levels. It was calculated that the four container terminals had \\
\hline Fuzzy data envelopment analysis & the lowest values at all $\alpha$ cutting levels regarding the maximum efficiency loss values of \\
\hline Minimax regret approach & other container terminals. \\
\hline
\end{tabular}

Please cite this paper as follows:

Yüksekyıldız, E., Tunçel, A. L. (2020). Determining the relative efficiency of container terminals in Turkey using fuzzy data envelopment analysis. Marine Science and Technology Bulletin, 9(2): 102-113

\section{Introduction}

Maritime transport, acknowledged as the lowest-cost option among transportation models (Keskin, 2011), is the most preferred means for transportation, allowing large volumes of cargo to be transported at once and minimizing the loss of property, as well as being safe and environmentally friendly (Ateş and Esmer, 2013). Maritime transport comprises

* Corresponding author

E-mail address: ercan.yuksekyildiz@samsun.edu.tr (E. Yüksekyıldız) three main components, which are the vessels, the cargo, and the ports (Ateş, 2010). Ports constitute vital connection points of the international trade chain (Bray et al., 2014). Maritime transport is now rapidly moving towards containerization. Container transportation comprised 102 million tons in 1980 and reached 1834 million tons in 2017 (UNCTAD, 2018). Therefore, competition in the market has gradually increased and ports must seek ways to become more modernized, rapid, 
and efficient in order to gain a larger share of the market (Oğuz, 2018). Container terminals need to be highly productive and must work efficiently in an environment in which the developments in world trade are rapid and competition is intense (Wang et al., 2017). Productive and efficient operation of terminals is one of the most important factors that increase the productivity of maritime transport (Ateş, 2010).

Productivity, which may be defined as the division of produced output values into the values used as input, is one of the most important performance indicators for companies, economies, and processes (Krajewski et al., 2015). Efficiency, on the other hand, is the ability to deliver a product or service using minimal resources (Tangen, 2005). It would not be reasonable to expect an increase in productivity values without also increasing efficiency values; however, a company with low productivity values could be efficient. Therefore, efficiency could be acknowledged as an element of productivity (Kök, 1991). When the literature is reviewed, it is seen that the concepts of efficiency and productivity have been used interchangeably and there is no consensus on these terms (Zengin and Taşdöven, 2015).

In this study, calculations are performed using fuzzy data envelopment analysis (FDEA) to determine the relative efficiencies of ports in Turkey with container terminals. Following the information on maritime transport and efficiency provided in the first section, a literature review will be given in Section 2. In the third section, the efficiency measurements of 22 container terminals are presented after providing information on FDEA and the "set of a cuts approach." In the final section, the findings are interpreted together with discussions on the operations required for terminal ports to be more productive.

\section{Literature Review}

It is seen that different methods are used in the literature on performance measurement in ports. These methods are; The calculation of the load handling efficiency at the docks (Bendall and Stent, 1987; Tabernacle, 1995; Ashar, 1997), the measurement of the efficiency of a single factor (De Monie, 1987), the performance measurements for comparing the port's optimal handling capacity with the handling in a given time period (Talley, 1988), the estimation of the port cost function (Neufville and Tsunokawa, 1981), the calculation of the total efficiency factor of a port (Kim and Sachish, 1986) and the establishment of the port performance and efficiency model with multiple regression analysis (Tongzon, 1995). The most commonly used techniques are Regression Analysis, Cost Benefit and Cost Effectiveness Analysis, Stochastic frontier analysis, Simulation, Data Envelopment Analysis-DEA) and
Malmquist Analysis. Among these methods, simulation method and data envelopment analysis methods are used extensively in port efficiency and performance measurements (Esmer, 2009).

Data envelopment analysis plays an important role in determining the relative efficiencies of ports. The first study in the literature on port efficiency was conducted in 1993 by Roll and Hayuth (1993). This study was a theoretical assessment of efficiency rather than implementation. Later, Tongzon (1995), Poitras et al. (1996), and Martinez-Budria et al. (1999) tried to determine port efficiencies using the DEA method. The number of studies on port efficiency has increased since 2000. Tongzon (2001), in a study that applied DEA CCR (Charnes, Cooper, and Rhodes) and BCC (Banker, Charnes, and Cooper) models, calculated that the Rotterdam, Yokohama, Melbourne, and Osaka ports were more efficient than other ports. Valentine and Gray (2001) compared the efficiencies of 31 ports in North America and Europe using the DEA-CCR method. Itoh (2002) used DEA to measure the efficiencies of Japanese container terminals between 1990 and 1999. That study revealed that DEA was an efficient method in measuring port efficiencies, and it was indicated that the Tokyo and Nagoya ports were efficient. Wang et al. (2003) used input-oriented CCR and BCC methods in their study aimed at measuring the efficiencies of 57 ports around the world. Barros (2003), based on efficiency measurements of container terminals in Portugal using DEA, asserted that revising port rules would positively affect port efficiency. Turner et al. (2004) investigated ports in the USA and Canada using the DEA method. They argued that larger ports were more efficient. Barros and Athanassiou (2004) conducted a study on input and output using DEA to measure the efficiencies of Greek and Portuguese ports. The results of that study emphasized that privatization could be a good solution to increase the productivity of ports. Al-Eraqi et al. (2008) scrutinized the efficiencies of 22 large container terminals in the Middle East and East Africa, and they claimed that physically larger ports were more efficient. Bichou (2013) performed an efficiency measurement of 420 container terminals. The results indicated that larger-scale ports, modernized and equipped with automation systems, were more efficient. Yuen et al. (2013) conducted efficiency measurements of 21 container terminals in China between 2003 and 2007. Based on the findings obtained via DEA, 3 terminals were efficient in those years. Schøyen and Odeck (2013) measured the efficiencies of Norwegian container terminals between 2002 and 2008 using the DEA method. The results of that study indicated that Norwegian ports had higher efficiency than other ports, and the authors argued that the ports needed to be physically larger to be more efficient. Rajasekar and Deo (2014) 
used the DEA method to determine the efficiencies of 8 ports in India between 1993 and 2011. According to the efficiency scores obtained, the physically larger ports were more efficient. It was also found that ports that were not efficient could become efficient with infra- and superstructure modernizations. AlMawsheki and Shah (2017) measured the efficiencies of container terminals operating in the Middle East.

Turning to studies in Turkey, Baysal et al. (2004) tried to reveal the efficiencies of 7 ports operated by the Turkish State Railways. For this purpose, input- and output-oriented DEA models were implemented under fixed-income and variableyield scale hypotheses, and the efficiency values for the ports were determined. Bayar (2005) used the DEA method in his study to measure the efficiency of container terminals in Turkey and suggested proposals for the potential improvement of unproductive terminals. Ateş (2010) applied the DEA method to the 2005-2009 data of 13 private or state-operated container terminals and found that the İzmir and MIP (Mersin International Port) ports were relatively the most efficient ports in the 5-year period. Ateş and Esmer (2011) determined the efficiency statuses of 15 Turkish container terminals using input- and output-oriented CCR and BCC models with 2010 data. DEA was used in Çağlar's (2012) study to determine the productivity of private ports in Turkey, and it was argued that relative analysis methods were not sufficient on their own to determine the potentials of port management. Ateş et al. (2013) examined the change in the efficiencies of 9 container terminals (Novorossiysk, Odessa, Varna, Batumi, Burgaz, Poti, Ilyichevsk, Constanta, and Trabzon), 5 of which were located in countries with coasts on the Black Sea and that were included in the European-Caucasian-Asian transport corridor (TRACECA) in the 2008-2009 period, as well as Russia, which was not included in the program. The efficiency values were calculated using DEA.

Ateş and Esmer (2013) investigated the efficiency change in 13 container terminals operating in Turkey before and after the 2009 global economic crisis. Relative efficiency values were measured using DEA and the changes in the efficiency values in a certain period were measured with the Malmquist total factor productivity (TFP) index. Ateş and Esmer (2014) evaluated the productivity of Turkish container terminals using free disposal hull (FDH) analysis and DEA. In a 2014 study by Güner et al. (2014) the operational efficiency levels of ports were examined by assessing the data pertaining to five ports privatized in 1997. Using DEA and the Malmquist TFP, 14 years of efficiency values were measured comparatively for 5 ports. Akgül et al. (2015) determined the efficiencies of container terminals using DEA. In a 2017 study by Acer and Timor (2017), the DEA method was implemented to determine the efficiencies of 20 container terminals. They made a comparison for redetermining the efficiencies of 16 similar ports using cluster analysis. Gökçek and Şenol (2018) determined the efficiencies of 28 container terminals in 9 Mediterranean countries using 2016 data. In that study, which was conducted using CCR and BCC input-oriented models, it was found that 4 ports were efficient with both methods.

Searching the literature for studies conducted to determine port efficiency using FDEA, several such works can be identified. Chen (2007) measured the efficiencies of the 20 terminals that had handled the most containers in 2004 in the Asian region using classical DEA and FDEA methods. A CCR model was used in that study and it was found that 10 terminals were efficient according to the results obtained from classical DEA. In calculations with FDEA, it was found that the segregation ability was more powerful. The study concluded that the efficiency scores obtained by classical DEA and FDEA were similar. Bray et al. (2015), who implemented the FDEA method using Tongzon's (2001) data, determined the efficiencies of 16 international container terminals using a CCR input-oriented model with six input and four output variables. The same values were used in both models; only the delay time value was expressed differently at three different levels (20\%, $30 \%$, and $40 \%$ ) using triangular fuzzy numbers. At the end of the calculations, it was concluded that the results obtained at the $30 \%$ level were acceptable for making a comparison with the classical DEA method. Although the efficiency values obtained by the two models were close to each other, it was found that 12 terminals were efficient and 4 terminals were inefficient, and one particular terminal was inefficient in FDEA while it was efficient in classical DEA. Wang et al. (2017) determined the efficiencies of 12 container terminals situated in Taiwan and its periphery using fuzzy DEA. Evaluations for 6 input and 7 output variables were performed verbally, and these values were transformed into fuzzy numbers. In that study, conducted with a CCR model that was both input- and output-oriented, 2 terminals were found to be partially efficient and the rest were not efficient. In another study by Wang and Han (2018), inputand output-oriented FDEA models were set up to calculate the efficiencies of container terminals in Taiwan and the countries surrounding it. In both models, 2 terminals were found efficient while the other terminals were relatively not efficient.

As seen from this brief review, studies conducted using classical DEA to measure port efficiency are popular in the literature. On the other hand, the number of studies conducted using FDEA is small. The present study may therefore provide a helpful contribution to the literature, as studies on ports using FDEA are insufficient while studies on other topics have increased gradually. 


\section{Material and Methods}

In this study, the FDEA method was used to calculate the relative efficiency of the container terminals operating in Turkey. The first study on DEA was conducted by Farrell (1957), in which the efficiencies of units were measured by linear programming using a single input variable and multiple output variables. The CCR model, named for the initials of Charnes, Cooper, and Rhodes (1978) was developed, in which multiple inputs and outputs were used as variables. With this method, measurements of general technical productivities were performed under constant returns to scale. The BCC model, named for the initials of Banker, Charnes, and Cooper (1984), was also proposed. This model enables the calculation of the scale and technical productivity separately under variable returns to scale. In the following years, DEA was improved by methods including multiplicative, non-oriented, and additive approaches (Aladağ et al., 2018).

Today, different FDEA models are being developed and implemented in many areas (industry, health, transportation, etc.). In this study, the data pertaining to container terminals were transformed into fuzzy values using Zimmermann's (2011) set of a cuts approach and the relative lower and upper limit efficiency values of the terminals were determined with FDEA using the EMS 1.3 software package with regard to the model proposed by Wang et al. (2005). For each $a$ cut level of the obtained efficiency values, the lowest values of maximum efficiency loss (MEL) were calculated with the minimax regret approach (Wang et al., 2005), and the calculation and comparison of the relative efficiencies of the terminals were conducted. For this purpose, the following steps were followed:

i. Determining decision-making units,

ii. Determining input and output variables,

iii. Determining lower and upper limit values of variables using the set of $a$ cuts approach,

iv. Calculating efficiency values of decision units with the FDEA method,

v. Ranking efficiency values using the minimax regret approach.

\section{Determination of Decision-Making Units (DMUs)}

It is important that the DMUs used in the implementation have a similar configuration and that the observation set be homogeneous for the FDEA results to be statistically significant. The exclusion of DMUs at the extremes is preferred (Şenol et al., 2019). In this context, only the terminals that handle 10,000 TEU or more were considered in this study, and it was ensured that the DMUs were homogeneous. The 22 container terminals included in the study are presented in Table 1.

Table 1. Container terminals included in the study

\begin{tabular}{llll}
\hline No. & Container Terminals & No. & Container Terminals \\
\hline 1 & Assanport (CP1) & 12 & Mersin International \\
2 & Cort (CP12) \\
3 & Asyaport (CP3) & 14 & Roda Port (CP14) \\
4 & Ege Gübre (CP4) & 15 & Samsunport (CP15) \\
5 & Evyap (CP5) & 16 & Yllport (CP16) \\
6 & Gemport (CP6) & 17 & Alsancak Port (CP17) \\
7 & Kumport (CP7) & 18 & TCDD Haydarpaşa \\
8 & Alport (CP8) & 19 & Mardaş (CP19) \\
9 & Limakport (CP9) & 20 & Borusan (CP20) \\
10 & Limaş (CP10) & 21 & DP World Yarımca \\
11 & Marport (CP11) & 22 & Port Akdeniz (CP22) \\
\hline
\end{tabular}

In the DEA method, it is required that the number of DMUs be $m+s+1$ or $2^{*}(m+s)$, where $m$ is the number of inputs and $s$ is the number of outputs, for the reliability of the research (Boussofiane et al., 1991). In this study, 4 input variables and 1 output variable were used. The number of DMUs was 22 . Therefore, both conditions were met for the number of DMUs.

\section{Determination of Input and Output Variables}

It is imperative that the input and output variables be selected attentively and that they be reliable for DEA, which is a data-oriented efficiency measurement method (Göktolga and Artut, 2014). In DEA models, the number of input and output variables should be high to obtain better discrimination. However, the input and output variables to be used should be operative for all forms of decision-making (Boussofiane et al., 1991). The input and output variables that are most preferred in the literature and that play an important role in determining the efficiencies of container terminals are used in this study as presented in Table 2.

Table 2. Input and output variables used in the study

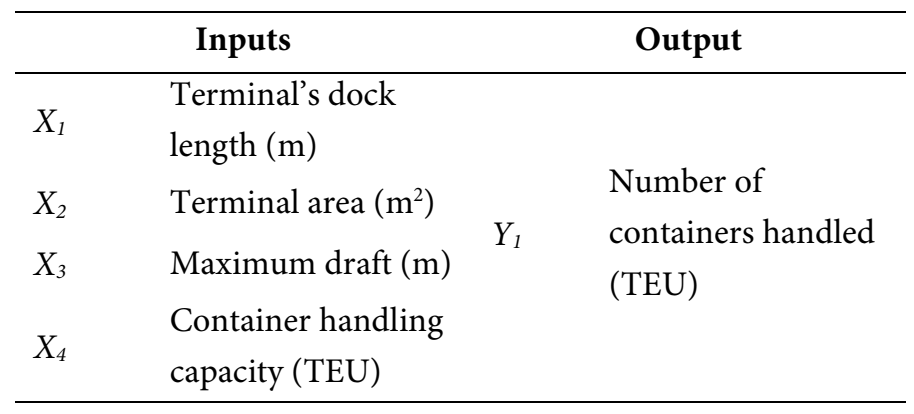


In this study, the efficiencies of the terminals were measured by the model prepared with 4 input variables and 1 output variable. The data used in the study were gathered from the information provided on the websites of TÜRKLIM (Port
Operators Association of Turkey), the Ministry of Transportation and Infrastructure, and the ports. The descriptive statistics for input and output variables are presented in Table 3.

Table 3. Descriptive statistics for input and output variables

\begin{tabular}{lcccrr}
\hline Input and output variables & Mean & Standard error & Standard deviation & Minimum & Maximum \\
\hline Terminal's dock length & 1666.182 & 197.5207 & 926.4544 & 405 & 3413 \\
Terminal area & 424543.5 & 65681.35 & 308072.8 & 90000 & 1200000 \\
Maximum draft & 17.22273 & 1.387341 & 6.507207 & 10 & 36 \\
Handling capacity & 931590.9 & 165133.6 & 774545 & 150000 & 2600000 \\
Number of containers handled in 2015 & 369221.5 & 96742.22 & 453761.2 & 2077 & 1576611 \\
Number of containers handled in 2016 & 395558.9 & 98376.9 & 461428.5 & 11463 & 1844015 \\
Number of containers handled in 2017 & 440978.5 & 100685.8 & 472258.4 & 11419 & 1709047 \\
\hline
\end{tabular}

\section{Determination of Lower and Upper Limit Values of}

\section{Variables}

Although data obtained from different sources are acknowledged as exact data, these data may vary due to incompleteness, errors, and alterations. These differences cause controversy regarding whether or not the data pertaining to the ports in Turkey are reliable. DEA is a technique that is extremely sensitive to data errors, and minute errors in gathering these data could lead to different efficiency scores being obtained.

In this study, it is considered that using FDEA would yield more reliable results to prevent the aforementioned errors. In the FDEA method, data are categorized into many classes such as limited, ordered, proportional, exact value known, or value unknown (Ebrahimi et al., 2018). If the lower and upper limit values of the data can be calculated, limited data may be obtained. Therefore, this study ensured the formation of fuzzy data by determining the lower, central, and upper limit values for the input and output values by a triangular membership function. Later, the fuzzy data were transformed into offset value data using Zimmermann's (2011) set of a cuts approach. The determination of the lower and upper limits, depending on the constancy of the variable data to be used in the study, could be performed in two ways.

\section{Determination of Lower and Upper Limit Values of}

\section{Non-Fixed Data}

As the number of containers handled (Y1), which is used as the output variable in determining the efficiencies of container terminals, shows variation for each year, it is a non-fixed variable. In order to transform these data into offset data, the 2015-2017 data pertaining to this variable are determined as the lower, central, and upper limits using the triangular membership function and fuzzy data are obtained. Later, lower and upper limit values are calculated at five different a levels using Zimmermann's (2011) set of a cuts approach.

$$
\begin{aligned}
& a_{\alpha}^{-}=a+\alpha(m-a) \\
& b_{\alpha}^{+}=b-\alpha(\mathrm{F} b-m)
\end{aligned}
$$

Here:

$a_{\propto}^{-}=$lower limit value of the variable at $\alpha$ cut level,

$b_{\propto}^{+}=$upper limit value of the variable at $\alpha$ cut level,

$a=$ lower limit value of the variable,

$b=$ upper limit value of the variable,

$m=$ central value of the variable.

For instance, the number of handled containers $\left(Y_{1}\right)$ in 2015, 2016, and 2017 in the Marport (CP11) container terminal is 1576611,1844015 , and 1709047 , respectively. These values are written as fuzzy triangular numbers as $[1576611 ; 1709047$; 1844015]. According to these data, the lower $\left(a_{\propto}^{-}\right)$and upper $\left(b_{\propto}^{+}\right)$limit values of variable $Y_{1}$ at the $\alpha=0.25$ cut level for the CP11 container terminal are calculated using Eq. 1 and Eq. 2 as follows:

$$
\begin{aligned}
a_{\propto}^{-} & =a+\propto(m-a)=1576611+0.25(1709047-1576611) \\
& =1609720 \\
b_{\propto}^{+} & =b-\propto(b-m)=1844015-0.25(1844015-1709047) \\
& =1810273
\end{aligned}
$$

When the same calculations are performed for other a cut levels, the lower and upper limit values in Table 4 are obtained for the variable of the number of handled containers $\left(Y_{1}\right)$ for the CP11 container terminal. 
Table 4. Lower and upper limit values of the $Y_{1}$ variable for the Marport container terminal according to a levels

\begin{tabular}{ccc}
\hline a cut level & Lower limit value & Upper limit value \\
\hline 0.00 & 1576611 & 1844015 \\
0.25 & 1609720 & 1810273 \\
0.50 & 1642829 & 1776531 \\
0.75 & 1675938 & 1742789 \\
1.00 & 1709047 & 1709047 \\
\hline
\end{tabular}

Determination of Lower and Upper Limit Values of

\section{Fixed Data}

Although the terminal's dock length $(\mathrm{m})$, terminal area $\left(\mathrm{m}^{2}\right)$, maximum draft $(\mathrm{m})$, and container handling capacity (TEU), which were used as input variables in this study, change over the years, the amount of this change may be ignored since it is minor enough to be deemed unimportant, especially for the period in which the efficiency analysis is being conducted. Therefore, these variables are considered as fixed data. These fixed data are transformed into fuzzy data using the following equations (Güneş, 2006):

$$
\begin{aligned}
& a=m-S_{h} \\
& b=m+S_{h}
\end{aligned}
$$

Here, $S_{h}$ is the standard error value. These values are calculated as lower and upper limits for five different $a$ values using Eq. 1 and Eq. 2. Accordingly, the lower and upper limits for the container handling capacity $\left(X_{4}\right)$ of the Marport (CP11) container terminal are calculated using Eq. 3 and Eq. 4 as follows:

$$
\begin{aligned}
& a=m-S_{h}=2400000-165133.6=2234866.4 \\
& b=m+S_{h}=2400000+165133.6=2565133.6
\end{aligned}
$$

These values could be expressed as triangular numbers as [2234866.4; 2400000; 2565133.6]. The lower $\left(a_{\propto}^{-}\right)$and upper $\left(b_{\propto}^{+}\right)$limits at the $\alpha=0.25$ cut level of the $X_{4}$ variable (offset value data) for the CP11 container terminal are then calculated as below using Zimmermann's (2011) set of a cuts approach:

$$
\begin{aligned}
a_{\propto}^{-} & =a+\propto(m-a)=2234866.4+0.25(2400000-2234866.4) \\
& =2276149.8 \\
b_{\propto}^{+} & =b-\propto(b-m)=2565133.6-0.25(2565133.6-2400000) \\
& =2523850.2
\end{aligned}
$$

When the same calculations are made for other a cut levels, the lower and upper limits of the container handling capacity $\left(X_{4}\right)$ for the CP11 container terminal, presented in Table 5, are obtained.
Table 5. Lower and upper limit values of the $X_{4}$ variable for the Marport container terminal according to a levels

\begin{tabular}{ccc}
\hline a cut level & Lower limit value & Upper limit value \\
\hline 0.00 & 2234866.4 & 2565133.6 \\
0.25 & 2276149.8 & 2523850.2 \\
0.50 & 2317433.2 & 2482566.8 \\
0.75 & 2358716.6 & 2441283.4 \\
1.00 & 2400000.0 & 2400000.0 \\
\hline
\end{tabular}

\section{Calculation of Efficiency Values of Decision-Making}

\section{Units with FDEA Method}

There are four main approaches in the literature for conducting efficiency measurements using FDEA: the tolerance approach, possibility approach, fuzzy ranking approach, and $a$ cuts approach. Besides these four primary groups, there are also some other approaches that could be considered within different categories (Hatami-Marbini et al., 2011; Emrouznejad et al., 2008). In this study, the FDEA method, which is based on the input-oriented CCR model following the method proposed by Wang et al. (2005) and which enables the lower and upper efficiency limits of the terminals to be obtained at five different a levels, was applied using the sets of a cuts approach. The CCR model calculates the inputs at minimum and the outputs at maximum. In addition, if the control over the inputs is low (or absent), an output-oriented model should be set up, and if the control over the outputs is low, an input-oriented model should be used (Dinc and Haynes, 1999). Since there is limited control over outputs in container handling terminals, an inputoriented model was preferred in this study. In this respect, the equations regarding the set of a cuts approach will be as follows:

Upper limit efficiency value:

$$
\begin{gathered}
\operatorname{Max}\left(\theta_{j 0}\right)_{\alpha}^{U}=\sum_{r=1}^{s} u_{r}\left(y_{r j 0}\right)_{\alpha}^{U} \\
\sum_{i=1}^{m} v_{i}\left(x_{i j 0}\right)_{\alpha}^{L}=1 \\
\sum_{r=1}^{s} u_{r} y_{r j}^{U}-\sum_{i=1}^{m} v_{i} x_{i j}^{L} \leq 0 \quad j=1, \ldots, n \\
u_{r}, v_{i} \geq \varepsilon, \quad \forall r, i .
\end{gathered}
$$

Upper limit efficiency value:

$$
\begin{gathered}
\operatorname{Max}\left(\theta_{j 0}\right)_{\alpha}^{L}=\sum_{r=1}^{s} u_{r}\left(y_{r j 0}\right)_{\alpha}^{L} \\
\sum_{i=1}^{m} v_{i}\left(x_{i j 0}\right)_{\alpha}^{U}=1 \\
\sum_{r=1}^{s} u_{r} y_{r j}^{U}-\sum_{i=1}^{m} v_{i} x_{i j}^{L} \leq 0 \quad j=1, \ldots, n \\
u_{r}, v_{i} \geq \varepsilon, \quad \forall r, i .
\end{gathered}
$$


Here:

$\theta_{j 0}^{U}$ is the upper limit efficiency value of the terminals to be analyzed,

$\theta_{j 0}^{L}$ is the upper limit efficiency value of the terminals to be analyzed,

$n$ is the number of terminals,

$i$ is the number of inputs $(i=1,2, \ldots, m)$,

$r$ is the number of outputs $(r=1,2, . ., s)$,

$y_{j}=\left\{y_{1 j}, y_{2 j}, \ldots, y_{r j}, \ldots y_{s j}\right\}$ is the $r$ th output value for the jth terminal,

$x_{j}=\left\{x_{1 j}, x_{2 j}, \ldots, x_{i j}, \ldots x_{s j}\right\}$ is the $i$ th input value for the $j$ th terminal,

$y_{r j}$ is the output vector for the $j$ th terminal,

$x_{i j}$ is the input vector for the $j$ th terminal,

$v_{i}$ is the input weights, $u_{r}$ is the output weights,

$L$ is the lower limit value for the terminal,

$U$ is the upper limit value for the terminal.

The set $\left[\theta_{j 0}^{L}, \theta_{j 0}^{U}\right]$ formed by the lower limit efficicency value $\left(\theta_{j 0}\right)_{\alpha}^{L}$ and upper limit efficiency value $\left(\theta_{j 0}\right)_{\alpha}^{U}$, calculated at different $\alpha$ cut levels to obtain fuzzy efficiency, is the relative best efficiency interval of the relevant DMU. The upper limit value of outputs and the lower limit value of inputs are used in calculating the upper limit efficiency value. In calculating the lower limit efficiency value, on the other hand, the lower limit values of the outputs and the upper limit values of the inputs are used (Güneş, 2006). The DMUs with calculated efficiency values equal to 1.00 are considered as efficient, while the DMUs with calculated efficiency values smaller than 1.00 are inefficient DMUs. The lower and upper efficiency values calculated at five different $a$ cut levels using Eq. 7 and Eq. 8 are presented in Table 6.

Table 6. Upper and lower limit efficiency values of the container terminals

\begin{tabular}{|c|c|c|c|c|c|c|c|c|c|c|}
\hline \multirow{2}{*}{ DMU } & \multicolumn{2}{|c|}{$\alpha=0.00$} & \multicolumn{2}{|c|}{$\alpha=0.25$} & \multicolumn{2}{|c|}{$\alpha=0.50$} & \multicolumn{2}{|c|}{$\alpha=0.75$} & \multicolumn{2}{|c|}{$\alpha=1.00$} \\
\hline & $\mathbf{U}$ & $\mathbf{L}$ & $\mathbf{U}$ & $\mathbf{L}$ & $\mathbf{U}$ & $\mathbf{L}$ & $\mathbf{U}$ & $\mathbf{L}$ & $\mathbf{U}$ & $\mathbf{L}$ \\
\hline $\mathrm{CP} 1$ & 1.000 & 0.354 & 1.000 & 0.421 & 1.000 & 0.502 & 0.898 & 0.603 & 0.735 & 0.735 \\
\hline CP3 & 1.000 & 0.133 & 0.923 & 0.275 & 0.846 & 0.416 & 0.773 & 0.559 & 0.703 & 0.703 \\
\hline $\mathrm{CP} 4$ & 0.791 & 0.687 & 0.840 & 0.736 & 0.908 & 0.790 & 0.951 & 0.852 & 0.922 & 0.922 \\
\hline CP6 & 0.593 & 0.631 & 0.649 & 0.661 & 0.720 & 0.695 & 0.772 & 0.732 & 0.772 & 0.772 \\
\hline CP7 & 0.717 & 0.468 & 0.714 & 0.530 & 0.710 & 0.590 & 0.707 & 0.648 & 0.704 & 0.704 \\
\hline CP8 & 0.191 & 0.036 & 0.113 & 0.040 & 0.079 & 0.044 & 0.066 & 0.049 & 0.056 & 0.056 \\
\hline СР9 & 0.353 & 0.192 & 0.352 & 0.229 & 0.352 & 0.266 & 0.348 & 0.304 & 0.342 & 0.342 \\
\hline CP10 & 0.128 & 0.052 & 0.110 & 0.056 & 0.099 & 0.061 & 0.086 & 0.067 & 0.076 & 0.076 \\
\hline CP14 & 1.000 & 0.439 & 1.000 & 0.490 & 1.000 & 0.560 & 1.000 & 0.660 & 0.817 & 0.817 \\
\hline CP15 & 0.458 & 0.204 & 0.403 & 0.221 & 0.377 & 0.242 & 0.353 & 0.270 & 0.306 & 0.306 \\
\hline CP16 & 0.580 & 0.518 & 0.587 & 0.525 & 0.593 & 0.533 & 0.578 & 0.542 & 0.552 & 0.552 \\
\hline CP17 & 0.916 & 0.871 & 0.908 & 0.873 & 0.901 & 0.877 & 0.895 & 0.882 & 0.888 & 0.888 \\
\hline CP18 & 0.249 & 0.169 & 0.246 & 0.184 & 0.242 & 0.199 & 0.240 & 0.216 & 0.235 & 0.235 \\
\hline CP19 & 0.530 & 0.431 & 0.531 & 0.450 & 0.532 & 0.470 & 0.524 & 0.491 & 0.513 & 0.513 \\
\hline CP20 & 0.912 & 0.646 & 0.917 & 0.684 & 0.926 & 0.729 & 0.893 & 0.783 & 0.847 & 0.847 \\
\hline CP21 & 0.463 & 0.002 & 0.361 & 0.016 & 0.260 & 0.029 & 0.158 & 0.043 & 0.056 & 0.056 \\
\hline
\end{tabular}




\section{Ranking of Efficiency Values by Minimax Regret}

\section{Approach}

As the efficiency value obtained by FDEA is considered as an interval, a simple and easily applicable method is required for the evaluation of these efficiencies. There are several approaches for the evaluation of interval numbers. However, the great majority of these methods are not powerful in discriminating interval numbers with the same centers but different widths. The minimax regret approach, developed by Wang et al. (2005) and frequently used in the literature, could be used to rank and compare the efficiency intervals of DMUs even if these DMUs are concentric and have different widths. According to the minimax regret approach:

Let $A_{i}=\left[a_{i}^{L}, a_{i}^{U}\right]=\left(m\left(A_{i}\right), w\left(A_{i}\right)\right)(i=1, \ldots, n)$ be the efficiency intervals of $n$ DMUs. The midpoints of the DMUs are:

$$
m\left(A_{i}\right)=\frac{1}{2}\left(a_{i}^{U}+a_{i}^{L}\right)
$$

and the widths of the DMUs are:

$$
w\left(A_{i}\right)=\frac{1}{2}\left(a_{i}^{U}-a_{i}^{L}\right)
$$

Let $A_{i}=\left[a_{i}^{L}, a_{i}^{U}\right]$ be selected as the best efficiency interval without exceptions, and let $b=\left[\max _{j \neq i}\left\{a_{j}^{U}\right\}\right]$. In this case:

a) if $a_{i}^{L}<b$, then the decision maker would experience efficiency loss and feel regret. The MEL is:

$$
\max \left(r_{i}\right)=b-a_{i}^{L}=\max _{j \neq i}\left\{a_{j}^{U}\right\}-a_{i}^{L}
$$

b) if $a_{i}^{L} \geq b$, the decision maker would not experience efficiency loss or feel regret. In this case, the regret of the decision maker is defined as zero, i.e. $r_{i}=0$. When these two cases are considered, the following is obtained:

$$
\max \left(r_{i}\right)=\max \left[\max _{j \neq i}\left(a_{j}^{U}\right)-a_{i}^{L}, 0\right]
$$

Therefore, the minimax regret criterion would select the best efficiency interval, which fulfils the condition below:

$$
\min _{i}\left\{\max \left(r_{i}\right)\right\}=\min _{i}\left\{\max \left[\max _{j \neq i}\left(a_{j}^{U}\right)-a_{i}^{L}, 0\right]\right\}
$$

Based on the analysis above, with the aim of comparing and ranking the productivity intervals, let $A_{i}=\left[a_{i}^{L}, a_{i}^{U}\right]=$ $\left(m\left(A_{i}\right), w\left(A_{i}\right)\right)(i=1, \ldots, n)$ be an efficiency interval set. The MEL for each efficiency interval $A_{i}$ could be calculated as follows:

$$
R\left(A_{i}\right)=\max \left[\max _{j \neq i}\left(a_{j}^{U}\right)-a_{i}^{L}, 0\right]
$$

$$
\begin{gathered}
=\max \left[\max _{j \neq i}\left\{m\left(A_{j}\right)+w\left(A_{j}\right)\right\}-\left(m\left(A_{i}\right)-w\left(A_{i}\right)\right), 0\right], \\
i=1, \ldots, n
\end{gathered}
$$

The minimum efficiency interval is the most attractive efficiency interval. The MELs, which are relevant numbers, are calculated according to the maximum efficiency among all other efficiency losses; however, these could not be used directly to rank them. The following elimination steps are proposed to produce a ranking using the MELs:

Step 1: MELs are calculated for all efficiency intervals, and the most attractive efficiency with the lowest efficiency loss is selected. Let us assume $A_{i_{1}}$ is selected considering $1 \leq i_{1} \leq n$.

Step 2: The selected $A_{i_{1}}$ is eliminated; the MEL for the remaining $(n-1)$ an efficiency interval is calculated again and the most attractive efficiency interval is determined. Let us assume $A_{i_{2}}$ is selected considering $1 \leq i_{2} \leq n, i_{2} \neq i_{1}$.

Step 3: Here, $A_{i_{2}}$ is eliminated, the MEL for the remaining ( $n$ - 2) an efficiency interval is calculated again, and the most attractive efficiency interval $A_{i_{2}}$ is selected.

Step 4: The elimination process is repeated until a single efficiency interval $A_{i_{n}}$ remains. Here the ">" sign means "superior," and the ranking is $A_{i_{1}}>A_{i_{2}}>\cdots>A_{i_{n}}$.

In this study, while the CP11 (Marport) terminal was found fully efficient, having lower and upper limit efficiency values at all a cut levels equal to 1.00 , the efficiencies of the remaining 21 terminals were measured as fuzzy numbers. The elimination steps mentioned above were applied to rank the fuzzy efficiency scores of the terminals found inefficient using the minimax regret approach. When MEL values are ranked from lowest to highest, the ranking of the fuzzy efficiency scores from best to worst is obtained as presented in Table 7.

\section{Results and Discussion}

The efficiencies of 22 container terminals operating in Turkey between 2015 and 2017 were evaluated using the FDEA method. Using the lower and upper limit values calculated at five different $\alpha$ cut levels together with Zimmermann's (2011) set of a cuts approach, the lower and upper limit efficiency values were determined with the FDEA model proposed by Wang et al. (2005). Later, the MEL values were calculated with the minimax regret approach and the efficiencies of the container terminals were ranked from best to worst.

The results of the FDEA calculations indicate that the CP11 container terminal is efficient at all a levels and the other terminals are relatively not efficient. In order to rank the inefficient container terminals, the MEL values should be 
considered. The values in Table 7 rank the MELs of the container terminals from best to worst. Here, a terminal with less efficiency loss is ranked as a better terminal. According to the MEL values, the CP11 container terminal is ranked first and the CP12 terminal is ranked second. The CP17 terminal has the lowest efficiency loss values at three a levels $(0.00,0.25,0.50)$ and is ranked third in these cases, while it is ranked fourth and fifth at the 0.75 and 1.00 a levels, respectively. The CP5 terminal ranked third at $\alpha=0.75$ and the $\mathrm{CP} 4$ terminal ranked third at $\alpha=1.00$, having the lowest efficiency losses at these levels, respectively.

Table 7. Maximum efficiency loss (MEL) values of the container terminals according to a levels

\begin{tabular}{|c|c|c|c|c|c|c|c|c|c|c|c|c|c|c|}
\hline \multicolumn{3}{|c|}{$\alpha=0.00$} & \multicolumn{3}{|c|}{$\alpha=0.25$} & \multicolumn{3}{|c|}{$\alpha=0.50$} & \multicolumn{3}{|c|}{$\alpha=0.75$} & \multicolumn{3}{|c|}{$\alpha=1.00$} \\
\hline No. & DMU & MEL & No. & DMU & MEL & No. & DMU & MEL & No. & DMU & MEL & No. & DMU & MEL \\
\hline 1 & CP11 & 0 & 1 & CP11 & 0 & 1 & CP11 & 0 & 1 & CP11 & 0 & 1 & CP11 & 0 \\
\hline 2 & CP12 & 0.0306 & 2 & CP12 & 0.0443 & 2 & CP12 & 0.0574 & 2 & CP12 & 0.0699 & 2 & CP5 & 0 \\
\hline 3 & CP17 & 0.1288 & 3 & CP17 & 0.1264 & 3 & CP17 & 0.1226 & 3 & CP5 & 0.1166 & 3 & $\mathrm{CP} 4$ & 0 \\
\hline 4 & $\mathrm{CP} 4$ & 0.3122 & 4 & $\mathrm{CP} 4$ & 0.2636 & 4 & $\mathrm{CP} 4$ & 0.2092 & 4 & CP17 & 0.1176 & 4 & CP12 & 0 \\
\hline 5 & CP20 & 0.3536 & 5 & CP5 & 0.3153 & 5 & CP5 & 0.2174 & 5 & $\mathrm{CP} 4$ & 0.1477 & 5 & CP17 & 0 \\
\hline 6 & CP6 & 0.3689 & 6 & CP20 & 0.3154 & 6 & CP20 & 0.2705 & 6 & CP20 & 0.2170 & 6 & CP20 & 0 \\
\hline 7 & CP13 & 0.3845 & 7 & CP6 & 0.3383 & 7 & CP6 & 0.3048 & 7 & CP6 & 0.2680 & 7 & CP14 & 0 \\
\hline 8 & CP5 & 0.4108 & 8 & CP13 & 0.3562 & 8 & CP13 & 0.3237 & 8 & CP13 & 0.2861 & 8 & CP6 & 0 \\
\hline 9 & CP16 & 0.4817 & 9 & CP7 & 0.4694 & 9 & CP7 & 0.4094 & 9 & CP14 & 0.3391 & 9 & CP13 & 0 \\
\hline 10 & CP7 & 0.5315 & 10 & CP16 & 0.4743 & 10 & CP14 & 0.4398 & 10 & $\mathrm{CP} 7$ & 0.3514 & 10 & $\mathrm{CP} 1$ & 0 \\
\hline 11 & CP14 & 0.5607 & 11 & CP14 & 0.5096 & 11 & CP16 & 0.4662 & 11 & $\mathrm{CP} 1$ & 0.3962 & 11 & CP7 & 0 \\
\hline 12 & CP19 & 0.5687 & 12 & CP19 & 0.5497 & 12 & $\mathrm{CP} 1$ & 0.4973 & 12 & $\mathrm{CP} 3$ & 0.4410 & 12 & $\mathrm{CP} 3$ & 0 \\
\hline 13 & CP22 & 0.5793 & 13 & CP22 & 0.5637 & 13 & CP19 & 0.5299 & 13 & CP16 & 0.4571 & 13 & CP16 & 0 \\
\hline 14 & $\mathrm{CP} 1$ & 0.6458 & 14 & $\mathrm{CP} 1$ & 0.5785 & 14 & CP22 & 0.5456 & 14 & CP19 & 0.5089 & 14 & CP19 & 0 \\
\hline 15 & CP15 & 0.7958 & 15 & CP3 & 0.7250 & 15 & $\mathrm{CP} 3$ & 0.5834 & 15 & CP22 & 0.5243 & 15 & CP22 & 0 \\
\hline 16 & СР9 & 0.8076 & 16 & СР9 & 0.7707 & 16 & СР9 & 0.7335 & 16 & CP9 & 0.6957 & 16 & СР9 & 0 \\
\hline 17 & CP18 & 0.8304 & 17 & CP15 & 0.7788 & 17 & CP15 & 0.7575 & 17 & CP15 & 0.7300 & 17 & CP15 & 0 \\
\hline 18 & CP3 & 0.8665 & 18 & CP18 & 0.8157 & 18 & CP18 & 0.8001 & 18 & CP18 & 0.7832 & 18 & CP18 & 0 \\
\hline 19 & CP10 & 0.9478 & 19 & CP10 & 0.9439 & 19 & CP10 & 0.9389 & 19 & CP10 & 0.9324 & 19 & CP10 & 0 \\
\hline 20 & $\mathrm{CP} 2$ & 0.9638 & 20 & $\mathrm{CP} 2$ & 0.9562 & 20 & $\mathrm{CP} 2$ & 0.9475 & 20 & $\mathrm{CP} 2$ & 0.9374 & 20 & $\mathrm{CP} 2$ & 0 \\
\hline 21 & CP8 & 0.9639 & 21 & CP8 & 0.9600 & 21 & CP8 & 0.9555 & 21 & CP8 & 0.9502 & 21 & CP8 & 0 \\
\hline 22 & CP21 & 0.9977 & 22 & CP21 & 0.9839 & 22 & CP21 & 0.9703 & 22 & CP21 & 0.9569 & 22 & CP21 & 0 \\
\hline
\end{tabular}

The CP10, CP2, CP8, and CP21 terminals had the highest efficiency loss values and they ranked as the last four terminals at all a levels. Considering that the CP10, CP2, and CP8 container terminals are the terminals that handle the fewest containers, it is normal for these terminals to be less efficient compared to others. The CP21 container terminal, on the other hand, had just been operationalized. Although the number of containers currently handled by this terminal is relatively high, the number of handled containers in 2015 and 2016 was low compared to other terminals in the same period; thus, CP2 1 appears to be the terminal with the lowest efficiency at all $\alpha$ levels. It is thought that this container terminal will be ranked more highly in the following years due to the increasing number of handled containers.

It is seen that the number of handled containers (Y1), used as an output variable, is the most important variable in efficiency ranking. Therefore, it can be argued that as the number of containers handled by a container terminal increase, that terminal's efficiency ranking will also increase.

In the future, other studies on efficiency measurements at ports handling different types of cargo (bulk, liquid, chemical, etc.) could be conducted using different FDEA models. More detailed results and new inferences could be obtained regarding efficiency since the discrimination ability of FDEA is better than that of classical DEA, and such results obtained via FDEA could offer information and guidance for the administrators of container terminals.

\section{Conclusions}

Container transportation is one of the most used types in maritime transportation. As container transportation has increased gradually, it becomes important in terminals 
handling such cargoes. The increasing number of large container ships causes the ports to operate in a competitive environment. Therefore, measuring the efficiency of container terminals is very important for international trade. In this study, fuzzy data envelopment analysis (FDEA) was conducted to determine the relative efficiency of the container terminals operating in Turkey.

The efficiencies of the container terminals were measured by the model prepared with 4 input variables and 1 output variable. The input and output variables of the container terminals have been converted to fuzzy numbers with set of $a$ cuts approach. Then the comparison and ranking of the container terminals was performed with the help minimax regret method. According to the results obtained from the study, only one container terminal is efficient at all $\alpha$ levels. This paper has also found that FDEA provides an effective method of evaluating relative port efficiency.

\section{Compliance with Ethical Standards}

\section{Authors' Contributions}

EY and ALT contributed to design and implementation of the research, to the analysis of the results and to the writing of the manuscript.

\section{Conflict of Interest}

The authors declare that there is no conflict of interest.

\section{Ethical Approval}

For this type of study, formal consent is not required.

\section{References}

Acer, A. \& Timor, M. (2017). The evaluation of Turkish container terminal efficiency using by data envelopment analysis (DEA). The Journal of Operations Research, Statistics, Econometrics and Management Information Systems, 5(2): 339-352. https://doi.org/10.17093/ alphanumeric.356455

Akgül, E. F., Fışkın, S. F., Düzalan, B., Erdoğan, T. \& Çetin, K. Ç. (2015). Liman rekabetçiliği ve etkinlik: Türkiye'deki konteyner limanları üzerine bir analiz. 2. Ulusal Liman Kongresi, İzmir, Turkey, 1-21. DOI: https://doi.org/10.18872/DEU.b.ULK.2015.0045.pdf

Aladağ, Z., Alkan, A., Güler, E. \& Özdin, Y. (2018). Performance evaluation of academic units with data envelopment analysis and promethee methods: A sample of Kocaeli University. Erciyes University Journal of Institute of Science and Technology, 34(1): 1-13.
Al-Eraqi, A. S., Mustafa, A., Khader, A. T. \& Barros, C. P. (2008). Efficiency of Middle Eastern and east African seaports: Application of DEA using window analysis. European Journal of Scientific Research, 23(4): 597-612.

Al-Mawsheki, E. S. A. (2017). Efficiency analysis of container ports in the Middle Eastern region. Ph.D. Thesis. Universiti Teknologi Malaysia. Johor Bahru, Johor, Malaysia.

Ashar, A. (1997). Counting the moves. Port Development International, 13: 25-29.

Ateş, A. \& Esmer, S. (2013). Effects of the 2009 global economic crisis on the Turkish container terminals. Journal of Turkish Court of Accounts/Sayistay Dergisi, 91: 105-125.

Ateş, A. (2010). Efficiency Analysis of Container Terminals at Turkey. Ph.D. Thesis. Atatürk University, Erzurum, Turkey.

Ateş, A. \& Esmer, S. (2011). DEA with efficiency analysis of Turkey container terminals. 12th International Symposium on Econometrics Statistics and Operations Research, Denizli, Turkey, pp. 29-38.

Ateş, A., Esmer, S. \& Şahin, T. (2013) VZA malmquist toplam faktör verimlilik ölçüsü: Karadeniz konteyner terminalleri uygulaması. I. Ulusal Liman Kongresi, İzmir, Turkey, pp. 407-428.

Ateş, A. \& Esmer, S. (2014). Calculation of container ports efficiency in Turkey with different methods. Verimlilik Dergisi, 1: 61-76.

Banker, R. D., Charnes, A. \& Cooper, W. W. (1984). Some models for estimating technical and scale inefficiencies in data envelopment analysis. Management Science, 30(9): 1078-1092. https://doi.org/10.1287/mnsc.30.9. $\underline{1078}$

Barros, C. P. (2003). The measurement of efficiency of Portuguese sea port authorities with DEA. International Journal of Transport Economics, 30(3): 335-354.

Barros, C. P. \& Athanassiou, M. (2004). Efficiency in European seaports with DEA: evidence from Greece and Portugal. Maritime Economics \& Logistics, 6(2): 122-140.

Baysal, M. E., Uygur, M. \& Toklu, B. (2004). A study of the relative efficiency of TCDD ports, using data envelopment analysis. Journal of Engineering and Architecture of Gazi University, 19(4): 437-442.

Bayar, S. (2005). Measuring of seaport's efficiency by using data envelopment analysis; an example from Turkish seaports. Master Thesis. İstanbul University, İstanbul, Turkey. 
Bendall, H. B., \& Stent, A. F. (1987). On measuring cargo handling productivity. Maritime Policy and Management, 14(4): 337-343.

Bichou, K. (2013). An empirical study of the impacts of operating and market conditions on container-port efficiency and benchmarking. Research in Transportation Economics, 42(1): 28-37. https://doi.org/10.1016/j.retrec.2012.11.009

Boussofiane, A., Dyson, R. G. \& Thanassoulis, E. (1991). Applied data envelopment analysis. European Journal of Operational Research, 52(1): 1-15.

Bray, S., Caggiani, L. Dell'Orco, M. \& Ottomanelli, M. (2014). Measuring transport systems efficiency under uncertainty by fuzzy sets theory-based data envelopment analysis. Procedia-Social and Behavioral Sciences, 111: 770-779.

Bray, S., Caggiani, L. \& Ottomanelli, M. (2015). Measuring transport systems efficiency under uncertainty by fuzzy sets theory-based data envelopment analysis: theoretical and practical comparison with traditional DEA model. Transportation Research Procedia, 5: 186-200. https://doi.org/10.1016/j.trpro.2015.01.005

Charnes, A., Cooper, W. W. \& Rhodes, E. (1978). Measuring the efficiency of decision-making units. European Journal of Operational Research, 2(6): 429-444.

Chen, S. H. (2007). Evaluating the operation performance of international container ports in Asia with fuzzy multiple objective DEA. Master Thesis. National Taiwan Ocean University, Taiwan.

Çağlar, V. (2012). Efficiency and productivity analysis in Turkish private ports. Ph.D. Thesis. Dokuz Eylül University, İzmir, Turkey.

De Monie, G. (1987). Measuring and evaluating port performance and productivity, UNTAD monograph on port management no. 6 and the international association of ports and harbour (IAPH).

Dinc, M. \& Haynes, K. E. (1999). Sources of regional inefficiency an integrated shift-share, data envelopment analysis and input-output approach. The Annals of Regional Science, 33(4): 469-489. https://doi.org/10.1007 /s001680050116

Ebrahimi, B., Tavana, M., Rahmani, M. \& Santos-Arteaga, F. J. (2018). Efficiency measurement in data envelopment analysis in the presence of ordinal and interval data. Neural Computing and Applications, 30(6): 1971-1982.
Emrouznejad, A., Parker, B. R. \& Tavares, G. (2008). Evaluation of research in efficiency and productivity: a survey and analysis of the first 30 years of scholarly literature in DEA. Socio-Economic Planning Sciences, 42(3): 151-157.

Esmer, S. (2009). Optimization of Logistics Processes at the Container Terminals and a Simulation Model. Ph.D. Thesis. Dokuz Eylül University, İzmir, Turkey.

Farrell, M. J. (1957). The measurement of productive efficiency. Journal of the Royal Statistical Society: Series A (General), 120(3): pp. 253-281. https://doi.org/10.2307/ $\underline{2343100}$

Güner, S., Coşkun, E. \& Taşkın, K. (2014). The impact of port privatization on the operational efficiency: a longitudinal study on Turkish ports. Istanbul University Journal of the School of Business, 43(2): 218-236.

Güneş, T. (2006). Fuzzy Data Envelopment Analysis. Master Thesis. Ankara University, Ankara, Turkey.

Gokcek, V. \& Şenol, Y. E. (2018). Efficiency analysis of Mediterranean container ports. Journal of ETA Maritime Science, 6(2): 129-140. https://doi.org/10.5505 ljems.2018.86648

Göktolga, Z. \& Artut, A. (2014). Efficiency measurement of faculties of economics and administrative sciences via fuzzy data envelopment analysis. Journal of Economics and Administrative Sciences, 15(1): 55-75.

Hatami-Marbini, A., Emrouznejad, A. \& Tavana, M. (2011). A taxonomy and review of the fuzzy data envelopment analysis literature: Two decades in the making. European Journal of Operational Research, 214(3): 457472.

Itoh, H. (2002). Efficiency changes at major container ports in Japan: A window application of data envelopment analysis. Review of Urban \& Regional Development Studies, 14(2): 133-152. https://doi.org/10.1111/1467940X.00052

Keskin, M. H. (2011). Kavramlar, Prensipler, Uygulamalar Lojistik El Kitabı \& Küresel Tedarik Zinciri Pratikler. 1st ed. Ankara, Turkey: Gazi Press. 722p.

Kim, M. \& Sachish, A. (1986). The structure of production, technical change and productivity in a port. The Journal of Industrial Economics, 35(2): 209-223.

Krajewski, L. J., Ritzman, L. P. \& Malhotra, M. K. (2015). Operations Management: Processes and Supply Chains. 12nd ed. United Kingdom: Pearson Education Limited. $672 \mathrm{p}$.

Kök, R. (1991). Efficiency and Productivity Analysis of Sugar Industry in Turkey. Erzurum, Turkey: Atatürk University Press. 285p. 
Martinez-Budria, E., Diaz-Armas, R., Navarro-Ibanez, M. \& Ravelo-Mesa, T. A. (1999). A study of the efficiency of Spanish port authorities using data envelopment analysis. International Journal of Transport Economics, 26(2): 237-253.

Neufville, R. D. \& Tsunokawa, K. (1981). Productivity and returns to scale of container ports. Maritime Policy and Management, 8(2): 121-129.

Oğuz, C. (2018). Karadeniz ve Marmara bölgelerinde uluslararası hat taşımacılığı yapılan konteyner limanlarındaki ortalama konteyner hareket tamamlama sürelerinin karşılaştırması ve maliyet analizi. Maritime Expertise Thesis. General Directorate of Maritime Trade, Ankara, Turkey. 133p.

Poitras, G., Tongzon, J. \& Li, H. (1996). Measuring port efficiency: An application of data envelopment analysis. Working paper. Singapore: Department of Economics and Statistics, National University of Singapore. 18p.

Rajasekar, T. \& Deo, M. (2014). Does size influence the operational efficiency of the major ports of India? -A study. IUP Journal of Operations Management, 13(1): 20.

Roll, Y. \& Hayuth, Y. (1993). Port performance comparison applying data envelopment analysis (DEA). Maritime Policy and Management, 20(2): 153-161. https://doi.org/10.1080/03088839300000025

Schøyen, H. \& Odeck, J. (2013). The technical efficiency of Norwegian container ports: A comparison to some Nordic and UK container ports using data envelopment analysis (DEA). Maritime Economics \& Logistics, 15(2): 197-221.

Şenol, O., Metin, A. \& Korucu, K. S. (2019). Comparison of countries with death indicators: Data envelopment analysis. Journal of Süleyman Demirel University Institute of Social Sciences, 2(33): 82-103.

Tabernacle, J. B. (1995). A study of the changes in performance of quayside container cranes. Maritime Policy and Management, 22(2): 115-124.

Talley, W. K. (1988). The role of US ocean ports in promoting an efficient ocean transportation system. Maritime Policy and Management, 15(2): 147-155.

Tangen, S. (2005). Demystifying productivity and performance. International Journal of Productivity and Performance Management, 54(1): 34-46.

Tongzon, J. L. (1995). Determinants of port performance and efficiency. Transportation Research Part A: Policy and Practice, 29(3): 245-252.
Tongzon, J. (2001). Efficiency measurement of selected Australian and other international ports using data envelopment analysis. Transportation Research Part A: Policy and Practice, 35(2): 107-122. https://doi.org/ 10.1016/S0965-8564(99)00049-X

Turner, H., Windle, R. \& Dresner, M. (2004). North American container port productivity: 1984-1997. Transportation Research Part E: Logistics and Transportation Review, 40(4): 339-356. https://doi.org/10.1016/j.tre.2003.06. $\underline{001}$

UNCTAD (2018). United Nations conference on trade and development. The Review of Maritime Transport, UNCTAD/RMT/2018, New York and Geneva. 102p.

Valentine, V. \& Gray, R. (2001). The measurement of port efficiency using DEA. Proceedings of the 9th World Conference on Transport Research, Vol. 22, Seoul, South Korea, pp. 27.

Wang, T. F., Song, D. W. \& Cullinane, K. (2003). Container port production efficiency: a comparative study of DEA and FDH approaches. Journal of the Eastern Asia Society for Transportation Studies, 5(10): 698-713.

Wang, Y. J., Meng, S. M. \& Han, T. C. (2017). Measuring the efficiency of international container ports with fuzzy DEA. 13th ICNC, Fuzzy Systems and Knowledge Discovery, Guilin, China, pp. 1339-1343.

Wang, Y. J. \& Han, T. C. (2018). Efficiency measurement for international container ports of Taiwan and surrounding areas by fuzzy data envelopment analysis. Journal of Marine Science and Technology, 26(2): 185193.

Wang, Y. M., Greatbanks, R. \& Yang, J. B. (2005). Interval efficiency assessment using data envelopment analysis. Fuzzy Sets and Systems, 153(3): 347-370.

Yuen, A. C., Zhang, A. \& Cheung, W. (2013). Foreign participation and competition: A way to improve the container port efficiency in China?. Transportation Research Part A: Policy and Practice, 49: 220-231. https://doi.org/10.1016/j.tra.2013.01.026

Zengin, C. \& Taşdöven, H. (2015). Emniyet hizmetlerinde verimlilik, etkililik ve performans: teorik ve pratik perspektifler. 1st ed. Ankara, Turkey: Nobel Akademik Press. 96p.

Zimmermann, H. J. (2011). Fuzzy set theory-and its applications, 4th ed. LLC, New York, USA: Springer Science \& Business Media. 541p. 